Wright State University

CORE Scholar

$12-2018$

\title{
Lakeshore Modification Reduces Secondary Production of Macroinvertebrates In Littoral But Not Deeper Zones
}

\author{
Marlene Pätzig \\ Yvonne Vadeboncoeur \\ Wright State University - Main Campus, yvonne.vadeboncoeur@wright.edu \\ Mario Brauns
}

Follow this and additional works at: https://corescholar.libraries.wright.edu/biology

Part of the Biology Commons, Medical Sciences Commons, and the Systems Biology Commons

\section{Repository Citation \\ Pätzig, M., Vadeboncoeur, Y., \& Brauns, M. (2018). Lakeshore Modification Reduces Secondary Production of Macroinvertebrates In Littoral But Not Deeper Zones. Freshwater Science, 37 (4), 845-856. \\ https://corescholar.libraries.wright.edu/biology/741}

This Article is brought to you for free and open access by the Biological Sciences at CORE Scholar. It has been accepted for inclusion in Biological Sciences Faculty Publications by an authorized administrator of CORE Scholar. For more information, please contact library-corescholar@wright.edu. 


\title{
Lakeshore modification reduces secondary production of macroinvertebrates in littoral but not deeper zones
}

\author{
Marlene Pätzig ${ }^{1,2,5}$, Yvonne Vadeboncoeur ${ }^{3,6}$, and Mario Brauns $\mathrm{s}^{4,7}$ \\ ${ }^{1}$ Department of Freshwater Conservation, BTU Cottbus-Senftenberg, Seestrasse 45, 15526 Bad Saarow, Germany \\ ${ }^{2}$ Working group: Small Water Bodies in Agricultural Landscapes, Research Platform "Data", Leibniz Centre for Agricultural \\ Landscape Research (ZALF), e.V., Eberswalder Strasse 84, 15374 Müncheberg, Germany \\ ${ }^{3}$ Department of Biological Sciences, Wright State University, 3640 Colonel Glenn Hwy, Dayton, OH 45435 USA \\ ${ }^{4}$ Working group: Food Web Ecology, Department of River Ecology, Helmholtz-Centre for Environmental Research (UFZ) Brückstrasse \\ 3 a, 39114 Magdeburg, Germany
}

\begin{abstract}
Littoral macroinvertebrates are an integral component of lake food webs, but their productivity may be affected by shoreline alteration. We hypothesized that human modification of lake shores simplifies habitat diversity, which, in turn, affects littoral macroinvertebrate production and patterns of depth-production relationships. Furthermore, we expected that lakeshore modification would favor nonnative species, potentially compensating for negative effects of lakeshore modification on production of native taxa. To test these ideas, we estimated benthic macroinvertebrate production in the upper littoral, middle littoral, and profundal zones of a large lowland lake (Lake Scharmützelsee) in Northeast Germany. We collected samples between April and November 2011 along depth transects established at both natural and modified shorelines. We found that production in the upper littoral zone was significantly lower at beaches than natural shores or marinas, but no difference existed between natural shorelines and marinas. The substantially lower production at beaches was correlated with lower habitat diversity, resulting from a lack of macrophytes. Additionally, production declined with increasing water depth at natural shores and marinas, but at beaches, production was highest in the middle littoral zone. Production of native taxa was lower at marinas than at natural shorelines, but production of nonnative species offset these declines. The increased productivity of nonnative species in upper littoral habitats at modified shorelines demonstrates that shoreline development has compromised the function of the littoral zone in Lake Scharmützelsee. Extrapolating depth- and habitat-specific production estimates to the entire lake showed that $33 \%$ of whole-lake benthic secondary production occurred in the upper littoral zone, even though this depth zone comprised only $7 \%$ of total lake area. Additionally, we estimated that completely replacing natural habitats with beaches would reduce whole-lake benthic secondary production by $24 \%$. Our results highlight the crucial role of the littoral zone for whole-lake ecosystem functioning and the high susceptibility of littoral benthic secondary production to lakeshore modification by human activities.
\end{abstract}

Key words: depth-production relationship, ecosystem functioning, habitat diversity, lake, nonnative species, shoreline development

A significant portion of benthic secondary production in lakes occurs in the littoral zone (e.g., Vadeboncoeur et al. 2002, Sierszen et al. 2014). Littoral macroinvertebrates are a major trophic link between primary producers and fish in lake ecosystems (Covich et al. 1999, Schindler and Scheuerell 2002), and macroinvertebrates can contribute $>60 \%$ of the diet (based on stable isotope estimates) of fish (Vander Zanden et al. 2006). Additionally, benthic filter feeders can alter lake ecosystem structure by regulating phytoplankton biomass and, thus, water transparency (MacIsaac 1996, Genkai-Kato et al. 2012). Secondary production is a direct measure of the role macroinvertebrates play in littoral carbon

E-mail addresses: ${ }^{5}$ marlene.paetzig@gmail.com; ${ }^{6}$ yvonne.vadeboncoeur@wright.edu; ${ }^{7}$ Present address: Working group: Food Web Ecology, Department of River Ecology, Helmholtz-Centre for Environmental Research (UFZ) Brückstrasse 3 a, 39114 Magdeburg, Germany 
flux and ecosystem functioning, but it is rarely quantified because measuring macroinvertebrate biomass and growth is time consuming.

In natural temperate and subpolar lakes, macroinvertebrate secondary production is typically highest in the upper littoral zone and declines monotonically with water depth (Lindegaard 1992, Babler et al. 2008, Butkas et al. 2011, Northington et al. 2010). The high productivity in the upper littoral zone is a result of warm temperatures, high oxygen availability, and high food quality (Downing 1984, Jónasson et al. 1990). In addition to having higher production, the littoral zone also has higher macroinvertebrate diversity because it is typically more heterogeneous than deeper zones of lakes that lack sufficient light and structural complexity (e.g., James et al. 1998, Heino 2000, Vadeboncoeur et al. 2011). Human modification of lakeshores and littoral zones reduces the abundance and changes the taxonomic composition of macroinvertebrate assemblages (Brauns et al. 2007, McGoff et al. 2013, Pätzig et al. 2015), but how these changes affect secondary production remains unknown. Shoreline development decreases habitat complexity when natural riparian vegetation is replaced with pavement or highly manicured vegetation, or when stakeholders remove within-lake habitat such as coarse woody debris, reed belts, or aquatic vegetation (Christensen et al. 1996, Francis and Schindler 2006, Radomski 2006). Alteration or loss of natural physical habitat structure may change the availability of organic matter resources that support secondary production (Francis et al. 2007, Rosenberger et al. 2008, Brauns et al. 2011). In some instances, however, shoreline development can increase habitat complexity by introducing new, sometimes novel, hard structures such as wood pilings or metal sheeting. In a previous study, we showed that these structures, and their indirect effects, can provide sufficient habitat to increase macroinvertebrate diversity (Pätzig et al. 2015), but it is not clear if this increase in diversity translates into higher secondary production.

Shoreline development may also facilitate the establishment of invasive species (Johnson et al. 2008, Brabender et al. 2016), especially in lakes connected to navigable rivers (Bobeldyk et al. 2005, Leuven et al. 2009). The New Zealand mud snail Potamopyrgus antipodarum (Gray, 1843) and the Ponto-Caspian zebra mussel Dreissena polymorpha (Pallas, 1771) are examples of widespread and successful invaders that can dominate secondary production and material flux in new habitats (Griffiths et al. 1991, Van der Velde et al. 2002, Hall et al. 2006, Alonso \& Castro-Díez 2012). Invasions can result in large increases in macroinvertebrate production as observed in Lake Simcoe (Canada) where $D$. polymorpha increased total secondary production $14 \times$ after establishment (Ozersky et al. 2012). If shoreline modification facilitates the establishment and persistence of nonnative invertebrates, total production may not change, or could substantially increase, in spite of reduction in littoral habitat complexity.
We hypothesized that reductions in habitat diversity caused by lakeshore modification would decrease production in the upper littoral zone, thereby altering the expected relationship between production and depth. We also hypothesized that the introduction of novel substrates into the littoral zone, which in our study occurred at marinas, may shift the contribution to production from a dominance of native to a dominance of nonnative species. Finally, we expected a decline in macroinvertebrate diversity and biomass caused by habitat simplification would be associated with a reduction in total macroinvertebrate production at the whole-lake scale.

\section{METHODS}

\section{Study site and sampling}

We measured benthic macroinvertebrate production at 3 depths in Lake Scharmützelsee, a stratified, mesotrophic lake in the Northeast German lowland (Fig. 1, Grüneberg et al. 2011). The lake has a surface area of $12.1 \mathrm{~km}^{2}$, a mean depth of $8.9 \mathrm{~m}$, and a maximum depth of $29.5 \mathrm{~m}$. It is connected to the navigable Dahme waterway system. Fifty seven percent of the lakeshore is undeveloped. Of the remaining lakeshore, 25\% has shore reinforcements such as sheet pil-

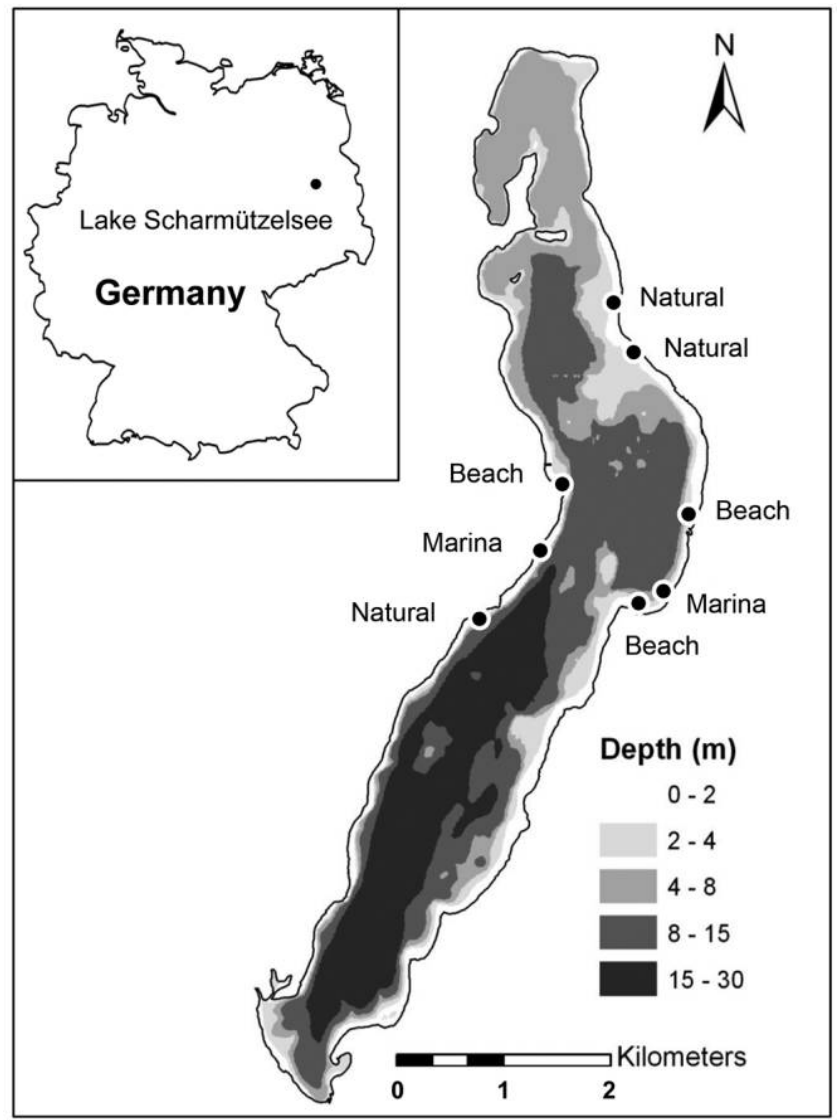

Figure 1. Lake Scharmützelsee and the positions of the 8 sampling transects. 
ings, and $18 \%$ is beaches, grasslands or parks (Fernando 2010).

We established 3 sampling transects at natural shorelines, 2 at marinas, and 3 at beaches. We incorporated the natural variation in wind and wave exposure by choosing 1 transect per shore type at the exposed east shore and 1 at the wind-sheltered western shore. Each transect was 30 to $50 \mathrm{~m}$ wide and comprised 1 homogenous shore type to avoid edge effects from neighboring habitats. The transects extended from the upper littoral zone (0-1.5-m water depth), through the middle littoral zone (1.5-4 m), and to the profundal $(>8 \mathrm{~m}$ ) zone (terminology following Hutchinson 1967) (Fig. 1). At natural transects, trees dominated the riparian vegetation, and the upper littoral zone contained dense reed belts. In contrast, the riparian vegetation of marinas and beaches was replaced by lawns. At marinas, natural habitats in the upper littoral zone, such as reed belts, had been replaced by sheet pilings and piers. In the upper littoral zone of beaches, natural habitats had been simplified to facilitate swimming, and thus consisted predominantly of sandy substrate (Pätzig et al. 2015).

We sampled macroinvertebrates from each transect in the upper littoral, middle littoral, and upper profundal zone. We sampled 2 natural shores, 1 marina, and 1 beach monthly from April to November 2011 and sampled the remaining 4 transects in April, July, September and November 2011. We sampled $1 / 2$ of the transects less frequently because of limited resources for sampling and laboratory work. We did not sample during winter because macroinvertebrate growth is slowed by low water temperatures, which likely resulted in an overestimation of total annual production (Dolbeth et al. 2012).

We sampled benthic macroinvertebrates from all habitats that occurred within each transect, including reed, stones, soft bottom, submerged macrophytes, and 2 types of artificial substrates (sheet piling and piles) following Pätzig et al. (2015). At each depth, we matched sampling effort with the relative surface area of each habitat type. For soft-bottom sediments and submerged macrophytes, we used a D-frame net with 500- $\mu \mathrm{m}$ mesh to sample the upper littoral zone and a Van-Veen-grab $(30 \times 20 \mathrm{~cm}$ wide $)$ to sample the deeper zones. Separating submerged macrophytes from the remaining sample was done with a 10-mm box sieve. Reed was sampled by cutting 10 stems between the lake bottom and the water surface. In the laboratory, macroinvertebrates attached to emergent and submerged macrophytes were collected alive from the plants and added to the corresponding macroinvertebrate sample. For sheet pilings and timber sheet piles, we used a scrape net $(500-\mu \mathrm{m}$ mesh). Stones were collected randomly and macroinvertebrates were brushed off carefully. After sampling, we pooled between one and four habitat-specific samples into a single composite sample (total area of $0.18 \mathrm{~m}^{2}$ ) for each depth in each transect and stored them for further processing in $70 \%$ ethanol. We then subsampled the composite samples following the methods of the AQEM Consortium (2002) and identified individuals to species or the lowest taxonomic level possible (for more details, see Pätzig et al. 2015). Information about nonnative taxa was obtained from the software ASTERICS version 4.0.4 (Schmidt-Kloiber et al. 2014).

\section{Environmental variables}

We collected environmental variables that were potentially associated with biological differences among shore types and depth zones. We calculated wind exposure (Brodersen 1995) to account for the effects of wind and waves at each location (Table 1). Wind data were obtained from a nearby weather station (Lindenberg $52^{\circ} 13^{\prime} \mathrm{N}, 14^{\circ} 07^{\prime} \mathrm{E}$; source: National Meteorological Service) between 2009 and 2011. We used ArcGIS (version 10; Environmental Research Systems Institute, Redlands, California) and maps with water depth contours (provided by the Ministry of Agriculture, Environment and Regional Development of

Table 1. Mean values $( \pm 95 \% \mathrm{CI})$ of environmental variables per shore type and depth zone. Habitat diversity was quantified as Hills number, relative wind exposure was calculated as $\log _{10}\left(1+f w h d^{-2}\right)$, where $f=$ mean weighted wind fetch $(\mathrm{km}), w=$ fraction of year with wind directed toward the station, $h=$ mean wind velocity $(\mathrm{m} / \mathrm{s})$, and $d=$ sampling depth $(\mathrm{m})$ (Brodersen 1995). Wind exposure $=$ relative wind exposure. $\mathrm{SOM}=$ sediment organic matter. $\mathrm{DM}=$ dry mass. Biomass $=$ reed and macrophyte biomass. Temp $=$ annual water temperature.

\begin{tabular}{|c|c|c|c|c|c|c|c|c|c|}
\hline \multirow[b]{2}{*}{ Variable } & \multicolumn{3}{|c|}{ Upper littoral } & \multicolumn{3}{|c|}{ Middle littoral } & \multicolumn{3}{|c|}{ Profundal } \\
\hline & Natural & Marina & Beach & Natural & Marina & Beach & Natural & Marina & Beach \\
\hline Habitat diversity & $2.1 \pm 0.2$ & $2.4 \pm 0.6$ & $1.5 \pm 0.7$ & $1.5 \pm 0.4$ & $1.7 \pm 0.6$ & $1.2 \pm 0.3$ & $1 \pm 0$ & $1 \pm 0$ & $1 \pm 0$ \\
\hline Wind exposure & $0.3 \pm 0.2$ & $0.4 \pm 0.0$ & $0.7 \pm 0.3$ & $0.1 \pm 0.1$ & $0.1 \pm 0.1$ & $0.1 \pm 0.1$ & $0.0 \pm 0.0$ & $0.0 \pm 0.0$ & $0.0 \pm 0.0$ \\
\hline Shore slope $\left(^{\circ}\right)$ & $1.7 \pm 0.5$ & $2.1 \pm 0.3$ & $1.6 \pm 0.1$ & $3.0 \pm 4.9$ & $6.8 \pm 6.7$ & $1.9 \pm 1.3$ & $7.0 \pm 10.0$ & $3.3 \pm 5.0$ & $2.5 \pm 1.8$ \\
\hline SOM (\%DM) & $2.3 \pm 1.5$ & $1.4 \pm 1.0$ & $1.1 \pm 0.5$ & $3.5 \pm 4.6$ & $3 \pm 4.5$ & $2.8 \pm 1.3$ & $20.7 \pm 0.0$ & $20.7 \pm 0.0$ & $20.7 \pm 0.0$ \\
\hline Biomass (DM g/m²) & $304 \pm 62$ & $35 \pm 33$ & $8 \pm 14$ & $26 \pm 22$ & $53 \pm 63$ & $72 \pm 109$ & $0 \pm 0$ & $0 \pm 0$ & $0 \pm 0$ \\
\hline Temp $\left({ }^{\circ} \mathrm{C}\right)$ & $11.9 \pm 0.1$ & $12.2 \pm 0.3$ & $12.4 \pm 0.2$ & $12.1 \pm 0.2$ & $12.0 \pm 0.2$ & $12.1 \pm 0.2$ & $9.0 \pm 0.6$ & $9.2 \pm 1.0$ & $9.0 \pm 0.6$ \\
\hline
\end{tabular}


the German Federal State Brandenburg [MLUL] 2002) to determine bed slope $\left(^{\circ}\right.$ ) of each depth zone (Table 1 ).

At each depth zone in each transect, we measured total macrophyte biomass as the sum of the dry weight of submerged macrophytes and reeds. Our estimates of submerged macrophytes and reed biomass were based on samples taken during peak biomass in September 2011. We used a D-frame net $\left(500-\mu \mathrm{m}\right.$ mesh, area $\left.0.16-0.18 \mathrm{~m}^{2}\right)$ to sample submerged macrophytes together with macroinvertebrates in the upper littoral and a Van-Veen-grab (area $0.18 \mathrm{~m}^{2}$ ) in deeper depth zones at each location. We quantified reed biomass in the upper littoral zone by determining stem density from an area of $0.16 \mathrm{~m}^{2}$ (dense stands) and $1 \mathrm{~m}^{2}$ (sparse stands) replicated $3 \times$ per transect. From each transect, we cut 10 stems between the water surface and the lake bottom, dried them at $60^{\circ} \mathrm{C}$ for $24 \mathrm{~h}$, and weighed them to the nearest $0.01 \mathrm{~g}$ (Table 1).

We also obtained measurements of the organic matter content in bottom sediments at each sampling location in each transect. In the upper and middle littoral zone, we took five $6-\mathrm{cm}$ diameter sediment cores. We then extracted the uppermost $2 \mathrm{~cm}$ of each core, dried it at $60^{\circ} \mathrm{C}$ for at least 12 hours, and determined ash-free dry mass (AFDM) by combusting samples for $3 \mathrm{~h}$ at $500^{\circ} \mathrm{C}$. We averaged unpublished AFDM data previously (April 2007) obtained by staff at Brandenberg University of Technology CottbusSenftenberg from 3 locations in the profundal zone near our transects. These data were treated with a similar procedure as described above.

We calculated mean annual temperature in each transect for the upper and middle littoral zones and for the profundal zone at east and west sides of the lake. We recorded water temperature with 16 temperature loggers in total (VEMCO Minilog; VEMCO Division, AMIRIX Systems Inc., Bedford, Canada) placed at each transect at upper (0.5-0.8-m depth) and middle littoral (2-m depth) zones at 20-min intervals from May through September 2011. We also used a multiparameter probe (Hydrolab DS5; OTT Hydromet, Kempten, Germany) to measure temperature $2 \times$ each month in different depths of the pelagic zone at various sites of Lake Scharmützelsee. We used these monthly temperature data to complete the logger data of the upper and middle littoral zones to calculate mean annual temperature during 2011 (Table 1). For all profundal sites, we used only the bi-monthly roughly $30-\mathrm{cm}$ interval measurements from the multiparameter probe at depths between 8 to $15 \mathrm{~m}$ (Table 1).

We characterized habitat diversity in each depth zone of each transect by counting the number of habitat types and visually estimating their percentage contribution to total area (Table 1). We used the Hill number, $N 1=\operatorname{Exp}\left(H^{\prime}\right)$ to quantify habitat diversity, because its properties allow direct comparison (Jost 2006). N1 is the exponential version of the Shannon index, $H^{\prime}=-\sum_{i}^{S} p_{i} \ln p_{i}$, where $\mathrm{p}_{\mathrm{i}}$ is the proportion of the area belonging to the $i^{\text {th }}$ habitat, and $S$ is the total number of all habitats (Jost 2006).

\section{Macroinvertebrate diversity, biomass, and secondary production between shore types and depth zones}

We also used the Hill number to quantify macroinvertebrate diversity, but in this case $p_{i}$ is the proportion of the individuals belonging to the $i^{\text {th }}$ species, and $S$ is the total number of all species (Jost 2006).

We estimated taxon-specific mean annual macroinvertebrate biomass by averaging taxon-specific mass across sampling dates after summing individual mass estimates obtained from taxon-specific length-mass relationships. We measured the body length from each individual to the nearest $0.01 \mathrm{~mm}$ with a digital microscope (Nikon SMZ 1500; Nikon, Düsseldorf, Germany). For 7 of 91 taxa we did not have enough measurements from our own data to accurately estimate length-mass relationship; therefore, we used literature-based length-mass regressions (Table S1 in Appendix). For the majority of observed taxa (83 of 91), we calculated individual dry mass (ash-free dry mass for Gastropoda and Sphaeriidae) based on allometric regression equations developed from our own data (Table S1 in Appendix, Mährlein et al. 2016). Back transformation of these log-log-regressions to the usually applied power function for the nonlinear length-mass relationship introduces a systematic underestimation into estimates. This underestimation arises because logged data predict geometric rather than the arithmetic mean mass. We, therefore, corrected our dry weight estimates with Duan's smearing factor, $\mathrm{SF}=\frac{1}{n} \sum_{i=1}^{n} e^{\varepsilon_{i}}$, where $\varepsilon_{\mathrm{i}}$ are the residuals from the fitted $\log$-linear model and $n$ is the number of observations (Duan 1983, Mährlein et al. 2016). We also applied conversion factors to correct for preservation effects for all dry mass (DM) estimates, because we used preserved specimens (Table S1, Mährlein et al. 2016). The final equation was $M_{S E}=$ $e^{\ln a+b \cdot \ln L} \cdot S F \cdot C F$, where $\mathrm{M}_{\mathrm{SE}}$ represents the mass $( \pm 1 \mathrm{SE})$, $\ln a$ and $b$ are the intercept and slope of the linear regression function, L is the length of body dimension, SF is Duan's smearing factor, and CF is the conversion factor from preserved to unpreserved mass (Mährlein et al. 2016). Additionally, estimating the DM of large individuals outside of the length range can lead to serious errors, because mass increases more rapidly for older, larger individuals than it does for younger, shorter ones (Johnston and Cunjak 1999). To avoid these errors, we assigned length measures of large individuals outside the specific length range of a taxon's regression to the maximum length value used in each regression. We only had to make this adjustment for $0.2 \%$ of almost 48,500 individuals across taxa. Dry mass of Oligochaeta (1 of 91 taxa) was determined directly by weighing fragmented individuals present in our samples to the nearest $0.01 \mathrm{mg}$.

We used the empirical, multiparameter artificial neural network (ANN) model developed by Brey et al. (Brey et al. 1996, Brey 2012) to estimate secondary production. Cohortbased production methods are prohibitively expensive because of the high number of samples needed to adequately characterize growth and biomass over time and space. ANNs are powerful machine learning techniques that represent a 
multilayer architecture of nodes (artificial neurons) that are highly interconnected. Based on self-learning, ANNs are able to generalize and, therefore, predict complex patterns when they are calibrated with training data (Dayhoff and DeLeo 2001). The Brey ANN model (Brey et al. 1996, Brey 2012) is based on the experiences gained from multiple linear regression models that describe relationships between production to biomass ratios $(\mathrm{P} / \mathrm{B})$ and various biotic and abiotic predictors (e.g. Banse and Mosher 1980, Plante and Downing 1989). It includes 20 input variables that account for the effects of organism traits (e.g. alimentation, feeding, and mobility type) and environmental conditions (e.g. type of water body, water temperature, and water depth) to estimate the $\mathrm{P} / \mathrm{B}$ ratio (Table $\mathrm{S} 2$ in Appendix). Of the 20 input variables, the average individual body mass for each taxon influences production estimates the most (Brey 2012). We used the geometric mean mass to calculate the average individual body mass for each taxon in the ANN model, because organism growth is an exponential function of time (Benke and Huryn 2007). After estimating the $P / B$ ratio for each taxon and sampling site with the ANN model, we estimated taxon-specific production by multiplying the $\mathrm{P} / \mathrm{B}$ ratio by taxon-specific mean annual biomass. Rare taxa, including Coleoptera, Heteroptera, Lepidoptera, other Diptera, Turbellaria, and Unionidae, with abundances $<1 \%$ of total annual abundance were excluded from the statistical analysis as their occurrences are subject to large uncertainties. By excluding Unionidae, we underestimated total biomass to some extent, but we do not expect that this error substantially affected production estimates because Unionidae grow slowly (Negus 1966).

Finally, we tested if differences in sampling frequency (4 transects in $8 \mathrm{~m}, 4$ transects in $4 \mathrm{~m}$ ) affected estimates of secondary production by comparing the production values based on the total dataset (including half of transects sampled at 8 and the other half at 4 dates) with a subset (4 dates) of the total dataset. We fit a major-axis regression ( $\mathrm{R}$ 3.4.1, function $m a$ from the package smart (Han and Liu 2015)) based on $\log (x)$-transformed data to examine correlations between the 2 different data sets. Production estimates based on 4 sampling dates were highly correlated with those from 8 dates $\left(R^{2}=0.97\right)$, indicating that the bias due to different sampling frequency was negligible. We, therefore, used all transects in further analyses without correcting for differences in sampling frequency.

\section{Statistical analyses}

Comparison among shore types and depth zones The small sample sizes ( $n=3$ for both beaches and natural sites and $n=2$ for marinas) precluded us from using inferential statistics to test for differences among shore types and depth zones. Instead, we interpreted 95\% confidence intervals (CIs) of habitat, species diversity, biomass, and secondary production estimates by considering means with nonoverlapping CIs as implying real differences between shore types and depth zones (Babler et al. 2008, Cross et al. 2011). Similarly, 95\% confidence intervals (CIs) and the proportions of native and nonnative production were calculated to account for shifts in dominance relations between shore types and depth zones.

Correlating habitat diversity with production To determine if secondary production was associated with habitat diversity across shore types and depth $(n=24)$, we conducted a linear regression analysis with the standard function $l m$ in R 3.4.1 (R Development Core Team 2017). Residuals of the fitted model were checked for normal distribution and homoscedasticity.

\section{Estimating whole-lake secondary production}

To estimate how changes in depth-specific production scale up to the whole lake, we $1^{\text {st }}$ estimated mean production for each shore type in the upper littoral. We then multiplied these values by the proportion of upper littoral area represented by the different shore types to estimate total production at this depth zone. For the middle littoral and profundal zone, we calculated mean production across all shoreline types, and multiplied these values with the area of each depth zone. We summed all zones to estimate wholelake benthic secondary production.

To determine how lakeshore development influenced secondary production at the lake-scale, we examined 7 scenarios that described how varying the amount of shoreline development changed whole-lake secondary production. The proportional amount of the 3 shore types to total shoreline length were set to range between 30 and $100 \%$. At the extremes of these scenarios, we calculated whole-lake littoral production assuming the entire upper littoral zone consisted of natural sites and compared this value with values based on scenarios where the entire upper littoral zone consisted of marinas or beaches, respectively. We propagated the individual errors of shoreline-specific production through each calculation and obtained a 95\% CI for the estimated whole-lake secondary production for each scenario. Scenarios were considered significantly different when 95\% CIs did not overlap.

\section{RESULTS}

\section{Effects of lakeshore modification on habitat diversity}

Habitat diversity appeared to differ between some shore types and depth zones, but not all (Fig. 2). In the upper littoral zone, beaches tended to have lower habitat diversity $(1.5 \pm 0.7)$ than natural sites $(2.1 \pm 0.3)$ or marinas $(2.4 \pm$ 0.6). No differences in habitat diversity were apparent between shore types based on data from middle littoral and profundal zones. Habitat diversity generally decreased with increasing depth irrespective of shore type. Mean habitat diversity across all shore types $( \pm 95 \% \mathrm{CI})$ in the upper littoral zone $(2 \pm 0.4)$ was not clearly different from that in the middle littoral $(1.5 \pm 0.2)$, but mean habitat diversity 


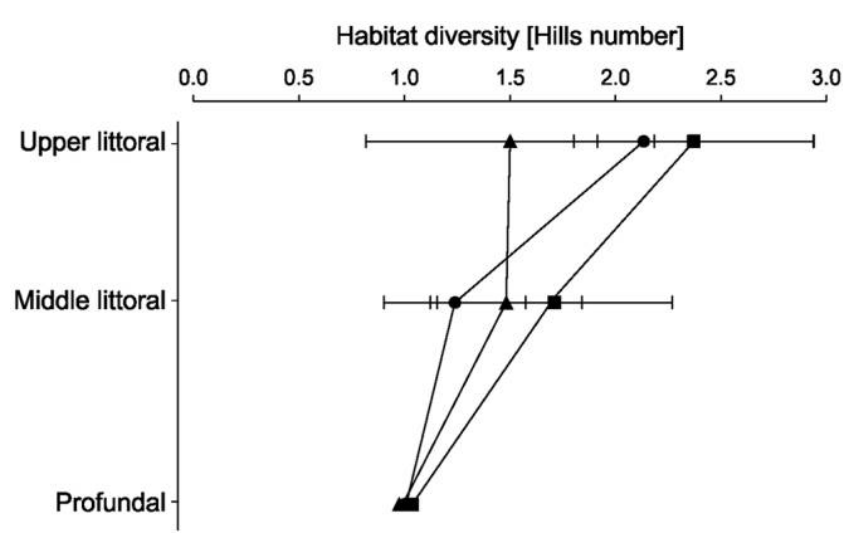

Figure 2. Habitat diversity quantified as Hills number for beaches (triangles), marinas (squares), and natural shorelines (circles) vs depth in Lake Scharmützelsee. Data are means and 95\% confidence intervals.

in both littoral zones was higher than that in the profundal zone $(1.0 \pm 0)$ (Fig. 2).

\section{Effect of lakeshore modification on macroinvertebrate diversity, biomass, and production}

Macroinvertebrate diversity, biomass, and production did not always exhibit expected patterns (Fig. 3A-D, Table 2). Diversity appeared to be clearly lowest in the profundal zone, but differences were less apparent between the two littoral zones (Fig. 3A). Mean annual biomass and annual secondary production in the upper littoral were significantly higher at natural sites than at beaches (Fig. 3B, C). There were no differences in biomass and secondary production among shore types in the middle littoral and profundal zone (Fig. 3B, C). Biomass and secondary production at natural sites and marinas were highest in the upper littoral and declined with increasing water depth. At beaches, biomass and secondary production were highest in the middle littoral and significantly lower in the upper littoral and profundal zones (Fig. 3B, C). However, production of only native species in the upper littoral zone at marinas was about $40 \%$ lower than that observed at natural shorelines. In the upper littoral zone of both modified shore types, nonnative taxa such as Potamopyrgus antipodarum and Pontogammaridae accounted for $\sim 1 / 2$ of the secondary production, whereas nonnative species contributed only $15 \%$ to secondary production in the upper littoral zone at natural transects (Fig. 3D). In the middle littoral zone, the contribution of native and nonnative taxa to total secondary production did not differ among the shore types (Fig. 3D). Nonnative taxa were absent from the profundal zone.

\section{Habitat diversity predicts secondary production}

We examined the potential of habitat diversity to predict benthic secondary production across shore types and depth zone. The model showed that habitat diversity was signifi- cantly positively related to secondary production (adjusted $R^{2}=0.68, F_{1,22}=49.2$ ) (Fig. 4).

\section{Effect of lakeshore modification on whole-lake secondary production}

Benthic secondary production weighted by area of shore type differed almost $30 \times$ across depth zones (Table 2). Mean production was 36,17 , and $1.3 \mathrm{~g} \mathrm{DW} \mathrm{m}^{-2} \mathrm{y}^{-1}$ in the upper littoral, middle littoral, and profundal zones, respectively (Table 2). At the whole-lake scale, 33\% of the benthic secondary production occurred in the upper littoral zone, although the surface area of this depth zone comprised only $7 \%$ of total lake area. The middle littoral zone contributed $>1 / 2$ of the estimated whole-lake benthic production, although it represented only $25 \%$ of the total lake area. Production in the profundal zone accounted for only $12 \%$ of whole-lake benthic production, even though the profundal zone covered almost $70 \%$ of the lake area.

Our scenario analysis showed that whole-lake macroinvertebrate production could range from $5.8 \pm 2.1$ (scenario with $100 \%$ beach), to $7.6 \pm 2.6$ (100\% marina), and $7.7 \pm 2.0$ (100\% natural shores) $\mathrm{g} \mathrm{DW} \mathrm{m}^{-2} \mathrm{y}^{-1}$. Thus, if the entire upper littoral zone consisted of beaches, production would be $24 \%$ lower than if the entire upper littoral zone consisted of natural shores or marinas.

\section{DISCUSSION}

Human shoreline development is a widespread practice that reduces littoral habitat complexity and degrades the ecological integrity of lakes (Christensen et al. 1996, Francis \& Schindler 2006, Brauns et al. 2011). We assessed whether a decrease in zoobenthic production accompanies the previously described reduction in benthic macroinvertebrate diversity associated with shoreline development (Brauns et al. 2007, Pätzig et al. 2015). In Lake Scharmützelsee, shoreline development lowered zoobenthic production in the upper littoral zone, altering the inverse relationship between production and water depth that is typical of natural shorelines. However, this alteration was only evident at beaches where modifications to promote the enjoyment of swimmers reduced littoral habitat heterogeneity. In contrast, areas of the lake modified for boating (marinas) contained novel substrates that supported high biomass of nonnative species. Zoobenthic production at marinas was comparable to that at natural shorelines, but nonnative species were a larger proportion of production at marinas.

Humans intentionally modify habitat complexity in littoral zones to promote specific uses. Beaches had the lowest habitat diversity of the 3 types of shoreline habitat in Lake Scharmützelsee because the structural complexity provided by macrophytes and reed beds is unsuitable for swimming areas (Table 1). In contrast, to support use by boats, marinas incorporated novel substrates such as sheet metal barriers and wood jetty pilings (Table 1). Macrophyte biomass at ma- 

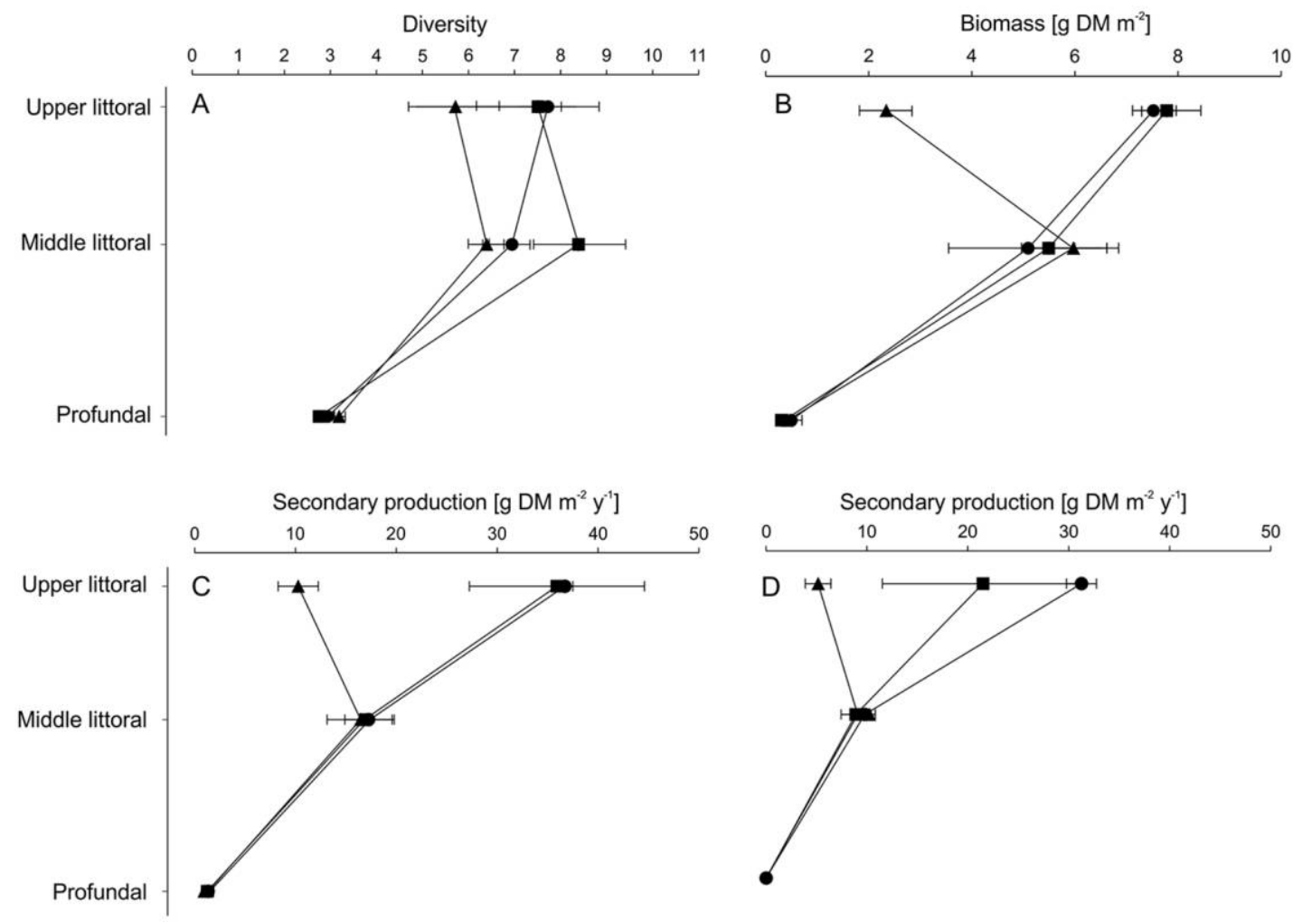

Figure 3. Macroinvertebrate diversity (A), biomass (B), total production (C), and production by native macroinvertebrates (D) for beaches (triangles), marinas (squares), and natural shorelines (circles) vs depth in Lake Scharmützelsee. Data are means and 95\% confidence intervals.

rinas was lower than in natural habitats, but they were not altogether absent. The natural shores of Lake Scharmützelsee lack much of the structural complexity provided by tree roots and coarse woody debris that is present in the littoral zones of many lowland lakes (Brauns et al. 2007, 2011). Thus, littoral habitat diversity in constructed marinas was comparable to that of natural areas, but the types of habitats that contributed to this diversity differed between the 2 shoreline types.

The low variation in habitat diversity among shoreline types was associated with low variation in macroinvertebrate diversity and a dominance in habitat generalists, such as Oligochaeta and Chironomidae. Beaches appeared to have slightly lower macroinvertebrate diversity than marinas or natural areas, but we had limited ability to detect differences in diversity among habitats because we excluded rare species (abundances $<1 \%$ ) from our analysis to improve secondary production estimates. In a previous publication on the same lake, we showed that rare species contributed to shorelinespecific responses of macroinvertebrate diversity to lakeshore modification (Pätzig et al. 2015).

There is abundant evidence from rivers and oceans that sand and mud support lower secondary production more than complex-structured habitats that include submerged wood or macrophytes (Benke et al. 1984, Grubaugh et al. 1997, Dolbeth et al. 2003, Wong et al. 2011). In lakes, littoral habitats with dense macrophyte beds typically support high macroinvertebrate diversity (e.g. James et al. 1998, Gabel et al. 2008, Thomaz and da Cunha 2010), and the limited data available suggests that secondary production in littoral zones is directly related to habitat structural complexity (Jónasson 1979, Gong et al. 2000). In Lake Scharmützelsee, marinas and natural shorelines had more types of habitats and higher macroinvertebrate biomass and secondary production than beaches, even when a component of that complexity was associated with human-created structures. Habitat diversity may generate higher secondary production because littoral zones consisting only of sand and mud have less total surface area for macroinvertebrates to colonize than littoral areas containing vertical surfaces that extend into the water column. Our data suggest that human modifications that add structure to the littoral zones (e.g., marinas) have a less obvious effect on total macroinvertebrate production than modifications (e.g., beach development) that simplify littoral areas.

Total macroinvertebrate production in marinas was similar to natural shorelines, because nonnative species, especially $P$. antipodarum, contributed greatly to secondary production at marinas with high habitat diversity and novel substrates. In contrast, although the proportion of nonnative species production to total production at beaches was 


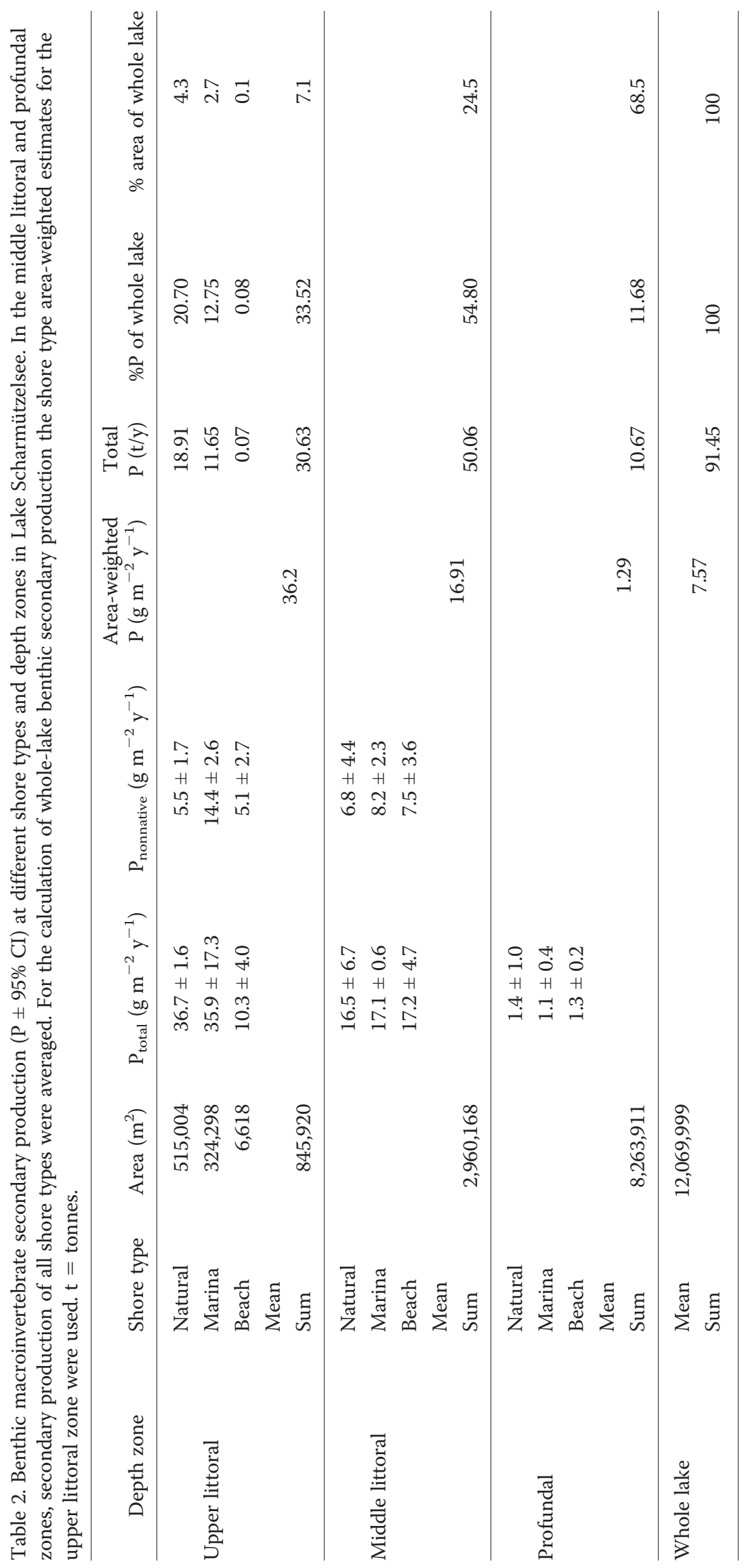

This content downloaded from 130.108.169.094 on January 29, 2019 07:47:55 AM 


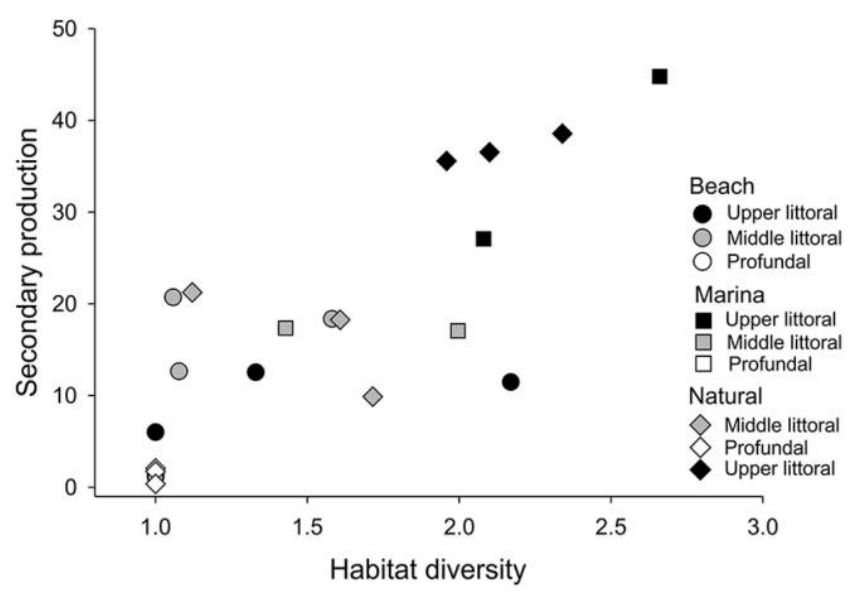

Figure 4. Associations between macroinvertebrate secondary production and habitat diversity (Hill number N1) across shore types (triangles $=$ beaches, square $=$ marinas, and circles $=$ natural shorelines) and depth zones (black $=$ upper littoral, gray $=$ middle littoral, and white $=$ profundal).

similar to marinas, nonnative species did not compensate for the loss of native species productivity at beaches, because of overall low habitat diversity. Similarly, Brabender et al. (2016) found that nonnative species contributed substantially to total secondary production in a large lowland river with abundant novel habitats (boulders). Modified shorelines of navigable rivers or lakes connected to them, such as Lake Scharmützelsee, are vulnerable to invasion by nonnative species, but the ability of nonnative species to compensate for native secondary production depends on the local habitat diversity and the level of physical disturbance (e.g., wave exposure, human trampling) (Table 1).

In lake littoral zones, habitat diversity and complexity often decreases with depth as light availability, wave action, and sediment particle size decrease (e.g., Rowan et al. 1992, Cyr 1998, Vadeboncoeur et al. 2011). Habitat diversity, macroinvertebrate biomass, and productivity declined with depth at marinas and natural shorelines, whereas macroinvertebrate productivity exhibited a unimodal relationship with depth at beaches. We suspect that macroinvertebrates in the upper littoral zone of beaches respond negatively to shoreline modifications that reduce habitat complexity, but that the mid-littoral zone was less affected by human activities. For instance, macrophytes were almost absent from the upper littoral zone at beaches, but macrophyte abundance in the middle littoral did not differ among lakeshore types. Secondary production was similar in this zone across all 3 shore types. Macroinvertebrates, such as Gyraulus crista L. (1758), that are typically associated with macrophytes were absent from the upper littoral zone of beaches, but contributed to secondary production of the middle littoral zone. To assess if the observed unimodal depth-productivity relationship is a general phenomenon at beaches requires further studies in other lake types.
The low habitat diversity in the upper littoral zone of beaches relative to marinas and natural shorelines may indicate lower food availability for macroinvertebrates at beaches (Brauns et al. 2011). Reeds, stones, and novel substrates were not present at beaches. These surfaces support the growth of attached algae and bacteria (periphyton), and this major food resource for macroinvertebrates (Vadeboncoeur and Power 2017) may have been less abundant at beaches. The availability of another food resource, benthic organic matter, was lower at developed shores compared with unmodified shores in lakes in the USA (Francis et al. 2007). However, in this study we found no significant differences among shore types in organic matter in sediments, an important resource for collector-gatherer species (Table 1). We did not measure all possible food types, and cannot critically evaluate the role resource availability or quality had in controlling secondary production.

Lakeshore modification also may alter secondary production by changing fish predation pressure. Decreases in resources and habitat availability at developed shores can reduce the densities of littoral fish (Scheuerell and Schindler 2004, Gaeta et al. 2011, Lewin et al. 2014). Low fish densities, in turn, may have released macroinvertebrates from predation at the marinas in our study, leading to the observed higher production. We could not test this hypothesis, though, because we did not estimate fish abundance in our study.

Our results support the generalization that macroinvertebrate production is highest in the littoral zone at natural shorelines (e.g. Kajak 1978, Dermott 1988, Lindegaard 1992, Babler et al. 2008, Butkas et al. 2011, Northington et al. 2010). However, we found that at beaches, habitat complexity, biomass, and productivity were all reduced relative to natural shorelines. When we simulated converting all of Lake Scharmützelsee's shoreline to beaches, whole-lake secondary production was reduced by $24 \%$. The effects of human lakeshore modification on whole-lake benthic secondary production are, therefore, less strong in lakes with naturally simple littoral zones or lakes with small littoral zones and steep slopes. It may, therefore, be important for managers to consider ways to mitigate negative impacts on littoral macroinvertebrates, which are key links between primary producers and fish, as well as between benthic and pelagic lake compartments (Vander Zanden et al. 2006).

\section{ACKNOWLEDGEMENTS}

Author contributions: MP and MB designed the study. MP conducted the fieldwork, the statistical analyses and writing of the manuscript. YV and MB contributed to the statistical analyses and writing of the manuscript.

We thank Brigitte Nixdorf, Björn Grüneberg and Jacqueline Rücker for supporting the research work, Ingo Henschke as well as Thomas Wolburg for the technical assistance and Andrew Dolman for statistical support. We thank Martin Pusch, Jürgen Schreiber and Marlen Mährlein for technical support and the 
help with taxonomy. We thank Ira Bobrowski, Anna-Katharina Buchberger, Juliane Hähnel, Regina Karantinos, Katrin Kluge, Patricia Penner, Joyce-Ann Syhre, Franziska Ullrich, Enrique Vazquez, Christopher Witrin and Benjamin Wulfert for their contribution on the processing of macroinvertebrate samples. We thank Thomas Brey for his patience in answering all our questions about the ANN model. The study was funded by a grant from the International Graduate School of the Brandenburg University of Technology Cottbus-Senftenberg and the German Limnological Society (DGL).

\section{LITERATURE CITED}

Alonso, Á., and P. Castro-Díez. 2012. The exotic aquatic mud snail Potamopyrgus antipodarum (Hydrobiidae, Mollusca): state of the art of a worldwide invasion. Aquatic Sciences 74:375-383.

AQEM CONSORTIUM. 2002. Manual for the application of the AQEM system. A comprehensive method to assess European streams using benthic macroinvertebrates, developed for the purpose of the Water Framework Directive. Version 1.0. (Available from: http://www.eu-star.at/frameset.htm)

Babler, A. L., C. T. Solomon, and P. R. Schilke. 2008. Depthspecific patterns of benthic secondary production in an oligotrophic lake. Journal of the North American Benthological Society 27:108-119.

Banse, K., and S. Mosher. 1980. Adult body mass and annual production/biomass relationships of field populations. Ecological Monographs 50:355-379.

Benke, A. C., and A. D. Huryn. 2007. Secondary production of macroinvertebrates. Pages 691-710 in F. R. Hauer and G. A. Lamberti (editors). Methods in stream ecology. $2^{\text {nd }}$ edition. Academic Press, San Diego, California.

Benke, A. C., T. C. Van Arsdall Jr., D. M. Gillespie, and F. K. Parrish. 1984. Invertebrate productivity in a subtropical blackwater river: the importance of habitat and life history. Ecological Monographs 54:25-63.

Bobeldyk, A. M., J. M. Bossenbroek, M. A. Evans-White, D. M. Lodge, and G. A. Lamberti. 2005. Secondary spread of zebra mussels (Dreissena polymorpha) in coupled lake-stream systems. Écoscience 12:339-346.

Brabender, M., M. Weitere, C. Anlanger, and M. Brauns. 2016. Secondary production and richness of native and non-native macroinvertebrates are driven by human-altered shoreline morphology in a large river. Hydrobiologia 776:51-65.

Brauns, M., X.-F. Garcia, N. Walz, and M. T. Pusch. 2007. Effects of human shoreline development on littoral macroinvertebrates in lowland lakes. Journal of Applied Ecology 44:1138-1144.

Brauns, M., B. Gucker, C. Wagner, X.-F. Garcia, N. Walz, and M. T. Pusch. 2011. Human lakeshore development alters the structure and trophic basis of littoral food webs. Iournal of Applied Ecology 48:916-925.

Brey, T. 2012. A multi-parameter artificial neural network model to estimate macrobenthic invertebrate productivity and production. Limnology and Oceanography: Methods 10:581-589.

Brey, T., A. Jarre-Teichmann, and O. Borlich. 1996. Artificial neural network versus multiple linear regression: predicting $\mathrm{P} / \mathrm{B}$ ratios from empirical data. Marine Ecology Progress Series 140:251-256.
Brodersen, K. P. 1995. The effect of wind exposure and filamentous algae on the distribution of surf zone macroinvertebrates in Lake Esrom, Denmark. Hydrobiologia 297:131-148.

Butkas, K. J., Y. Vadeboncoeur, and M. J. Vander Zanden. 2011. Estimating benthic invertebrate production in lakes: a comparison of methods and scaling from individual taxa to the whole-lake level. Aquatic Sciences 73:153-169.

Christensen, D. L., B. R. Herwig, D. E. Schindler, and S. R. Carpenter. 1996. Impacts of lakeshore residential development on coarse woody debris in north temperate lakes. Ecological Applications 6:1143-1149.

Covich, A. P., M. A. Palmer, and T. A. Crowl. 1999. The role of benthic invertebrate species in freshwater ecosystems: zoobenthic species influence energy flows and nutrient cycling. BioScience 49:119-127.

Cross, W. F., C. V. Baxter, K. C. Donner, E. J. Rosi-Marshall, T. A. Kennedy, R. O. Hall Jr., H. A. Wellard Kelly, and R. S. Rogers. 2011. Ecosystem ecology meets adaptive management: food web response to a controlled flood on the Colorado River, Glen Canvon. Ecological Applications 21:2016-2033.

Cyr, H. 1998. Effects of wave disturbance and substrate slope on sediment characteristics in the littoral zone of small lakes. Canadian Journal of Fisheries and Aquatic Sciences 55:967-976.

Dayhoff, J. E., and J. M. DeLeo. 2001. Artificial neural networks: opening the black box. Cancer: Supplement 91:1615-1635.

Dermott, R. M. 1988. Zoobenthic distribution and biomass in the Turkey Lakes. Canadian Journal of Fisheries and Aquatic Sciences 45:S107-S114.

Dolbeth, M., M. Cusson, R. Sousa, and M. A. Pardal. 2012. Secondary production as a tool for better understanding of aquatic ecosystems. Canadian Journal of Fisheries and Aquatic Sciences 69:1230-1253.

Dolbeth, M., M. A. Pardal, A. I. Lillebø, U. Azeiteiro, and J. C. Marques. 2003. Short- and long-term effects of eutrophication on the secondary production of an intertidal macrobenthic community. Marine Biology 143:1229-1238.

Downing, J. A. 1984. Assessment of secondary production: the first step. Pages 1-18 in Downing, J. A. and F. H. Rigler (editors). A manual on methods for the assessment of secondary productivity in fresh waters. $2^{\text {nd }}$ edition. Blackwell Scientific Publications, Oxford, UK.

Duan, N. 1983. Smearing estimate: a nonparametric retransformation method. Journal of the American Statistical Association 78:605-610.

Fernando, R. 2010. Hydromorphologic survey and assessment of the lakeshore of Lake Scharmützelsee as a prerequisite for the development of a lakeshore utilization strategy. Diplomica Verlag GmBH, Hamburg, Germany.

Francis, T. B., and D. E. Schindler. 2006. Degradation of littoral habitats by residential development: woody debris in lakes of the Pacific Northwest and Midwest, United States. AMBIO: A Journal of the Human Environment 35:274-280.

Francis, T. B., D. E. Schindler, J. M. Fox, and E. Seminet-Reneau. 2007. Effects of urbanization on the dynamics of organic sediments in temperate lakes. Ecosystems 10:1057-1068.

Gabel, F., X.-F. Garcia, M. Brauns, A. Sukhodolov, M. Leszinski, and M. T. Pusch. 2008. Resistance to ship-induced waves of benthic invertebrates in various littoral habitats. Freshwater Biology 53:1567-1578. 
Gaeta, J. W., M. J. Guarascio, G. G. Sass, and S. R. Carpenter. 2011. Lakeshore residential development and growth of largemouth bass (Micropterus salmoides): a cross-lakes comparison. Ecology of Freshwater Fish 20:92-101.

Genkai-Kato, M., Y. Vadeboncoeur, L. Liboriussen, and E. Jeppesen. 2012. Benthic-planktonic coupling, regime shifts, and whole-lake primary production in shallow lakes. Ecology 93:619-631.

Gong, Z., P. Xie, and S. Wang. 2000. Macrozoobenthos in 2 shallow, mesotrophic Chinese lakes with contrasting sources of primary production. Iournal of the North American Benthological Society 19:709-724.

Griffiths, R. W., D. W. Schloesser, J. H. Leach, and W. P. Kovalak. 1991. Distribution and dispersal of the Zebra Mussel (Dreissena polymorpha) in the Great Lakes Region. Canadian Journal of Fisheries and Aquatic Sciences 48:1381-1388.

Grubaugh, J. W., J. B. Wallace, and E. S. Houston. 1997. Production of benthic macroinvertebrate communities along a southern Appalachian river continuum. Freshwater Biology 37:581-596.

Grüneberg, B., J. Rücker, B. Nixdorf, and H. Behrendt. 2011. Dilemma of non-steady state in lakes - development and predictability of in-lake P concentration in dimictic Lake Scharmützelsee (Germany) after abrupt load reduction. International Review of Hydrobiology 96:599-621.

Hall Jr., R. O., M. F. Dybdahl, and M. C. VanderLoop. 2006. Extremely high secondary production of introduced snails in rivers. Ecological Applications 16:1121-1131.

Han, F., and H. Liu. 2015. smart: Sparse Multivariate Analysis via Rank Transformation. Version 1.0.1. (Available from: https:// CRAN.R-project.org $/$ package $=$ smart $)$

Heino, J. 2000. Lentic macroinvertebrate assemblage structure along gradients in spatial heterogeneity, habitat size and water chemistry. Hydrobiologia 418:229-242.

Hutchinson, G. E. 1967. A treatise on limnology. II. Introduction to lake biology and limnoplankton. John Wiley and Sons, New York.

James, M. R., M. Weatherhead, C. Stanger, and E. Graynoth. 1998. Macroinvertebrate distribution in the littoral zone of Lake Coleridge, South Island, New Zealand-effects of habitat stability, wind exposure, and macrophytes. New Zealand Journal of Marine and Freshwater Research 32:287-305.

Johnson, P. T. J., J. D. Olden, and M. J. Vander Zanden. 2008. Dam invaders: impoundments facilitate biological invasions into freshwaters. Frontiers in Ecology and the Environment 6:357-363.

Johnston, T. A., and R. A. Cunjak. 1999. Dry mass-length relationships for benthic insects: a review with new data from Catamaran Brook, New Brunswick, Canada. Freshwater Biology 41:653-674.

Jónasson, P. M. 1979. The Lake Mývatn ecosystem, Iceland. Oikos 32:289-305.

Jónasson, P. M., C. Lindegaard, and K. Hamburger. 1990. Energy budget of Lake Esrom, Denmark. Verhandlungen der Internationalen Vereinigung für theoretische und angewandte Limnologie 24:632-640.

Jost, L. 2006. Entropy and diversity. Oikos 113:363-375.

Kajak, Z. 1978. Characteristics of a temperate eutrophic, dimictic lake (Lake Mikołajskie, Northern Poland). Internationale Revue der gesamten Hydrobiologie und Hydrographie 63:451-480.
Leuven, R. S. E. W., G. van der Velde, I. Baijens, J. Snijders, C. van der Zwart, H. J. R. Lenders, and A. bij de Vaate. 2009. The river Rhine: a global highway for dispersal of aquatic invasive species. Biological Invasions 11:1989-2008.

Lewin, W.-C., T. Mehner, D. Ritterbusch, and U. Brämick. 2014. The influence of anthropogenic shoreline changes on the littoral abundance of fish species in German lowland lakes varying in depth as determined by boosted regression trees. Hydrobiologia 724:293-306.

Lindegaard, C. 1992. The role of zoobenthos in energy flow in deep, oligotrophic Lake Thingvallavatn, Iceland. Hydrobiologia 243/244:185-195.

MacIsaac, H. J. 1996. Potential abiotic and biotic impacts of zebra mussels on the inland waters of North America. Integrative and Comparative Biology 36:287-299.

Mährlein, M., M. Pätzig, M. Brauns, and A. M. Dolman. 2016. Length-mass relationships for lake macroinvertebrates corrected for back-transformation and preservation effects. $\underline{\text { Hydro- }}$ biologia 768:37-50.

McGoff, E., A. G. Solimini, M. T. Pusch, T. Jurca, and L. Sandin. 2013. Does lake habitat alteration and land-use pressure homogenize European littoral macroinvertebrate communities? Lournal of Applied Ecology 50:1010-1018.

Negus, C. L. 1966. A quantitative study of growth and production of unionid mussels in the River Thames. Iournal of Animal Ecology 35:513-532.

Northington, R. M., M. D. Keyse, S. R. Beaty, S. C. Whalen, E. R. Sokol, and A. E. Hershey. 2010. Benthic secondary production in eight oligotrophic arctic Alaskan lakes. Lournal of the North American Benthological Society 29:465-479.

Ozersky, T., D. O. Evans, and D. R. Barton. 2012. Invasive mussels alter the littoral food web of a large lake: stable isotopes reveal drastic shifts in sources and flow of energy. PLoS ONE 7: e51249.

Pätzig, M., B. Grüneberg, and M. Brauns. 2015. Water depth but not season mediates the effects of human lakeshore modification on littoral macroinvertebrates in a large lowland lake. Fundamental and Applied Limnology 186:311-321.

Plante, C., and J. A. Downing. 1989. Production of freshwater invertebrate populations in lakes. Canadian Journal of Fisheries and Aquatic Sciences 46:1489-1498.

R Development Core Team. 2017. R: a language and environment for statistical computing. R Foundation for Statistical Computing, Vienna, Austria. (Available from: https://www.r-project.org)

Radomski, P. 2006. Historical changes in abundance of floatingleaf and emergent vegetation in Minnesota lakes. North American Journal of Fisheries Management 26:932-940.

Rosenberger, E. E., S. E. Hampton, S. C. Fradkin, and B. P. Kennedy. 2008. Effects of shoreline development on the nearshore environment in large deep oligotrophic lakes. Freshwater Biology 53:1673-1691.

Rowan, D. J., J. Kalff, and J. B. Rasmussen. 1992. Estimating the mud deposition boundary depth in lakes from wave theory. Canadian Journal of Fisheries and Aquatic Sciences 49:2490-2497.

Scheuerell, M. D., and D. E. Schindler. 2004. Changes in the spatial distribution of fishes in lakes along a residential development gradient. Ecosvstems 7:98-106.

Schindler, D. E., and M. D. Scheuerell. 2002. Habitat coupling in lake ecosystems. Oikos 98:177-189. 
Schmidt-Kloiber, A., J. Strackbein, R. Vogl, M.T. Furse, and D. Hering. 2014. Description of the AQEM/STAR invertebrate database. Freshwater Metadata Journal 2:1-8. (Available from: http://dx.doi.org/10.15504/fmj.2014.2)

Sierszen, M. E., T. R. Hrabik, J. D. Stockwell, A. M. Cotter, J. C. Hoffman, and D. L. Yule. 2014. Depth gradients in food-web processes linking habitats in large lakes: Lake Superior as an exemplar ecosystem. Freshwater Biology 59:2122-2136.

Thomaz, S. M., and E. R. da Cunha. 2010. The role of macrophytes in habitat structuring in aquatic ecosystems: methods of measurement, causes and consequences on animal assemblages' composition and biodiversity. Acta Limnologica Brasiliensia 22:218-236.

Vadeboncoeur, Y., P. B. McIntyre, and M. J. Vander Zanden. 2011. Borders of biodiversity: life at the edge of the world's large lakes. BioScience 61:526-537.

Vadeboncoeur, Y., and M. E. Power. 2017. Attached algae: the cryptic base of inverted trophic pyramids in freshwaters. Annual Review of Ecology, Evolution, and Systematics 48:255-279.
Vadeboncoeur, Y., M. J. Vander Zanden, and D. M. Lodge. 2002. Putting the lake back together: reintegrating benthic pathways into lake food web models: lake ecologists tend to focus their research on pelagic energy pathways, but, from algae to fish, benthic organisms form an integral part of lake food webs. BioScience 52:44-54.

van der Velde, G., I. Nagelkerken, S. Rajagopal, and A. Bij de Vaate. 2002. Invasions by alien species in inland freshwater bodies in Western Europe: the Rhine delta. Pages 360-372 in E. Leppäkoski, S. Gollasch, and S. Olenin (editors). Invasive aquatic species of Europe. Distribution, impacts and management. Kluwer, Dordrecht, The Netherlands.

Vander Zanden, M. J., S. Chandra, S.-K. Park, Y. Vadeboncoeur, and C. R. Goldman. 2006. Efficiencies of benthic and pelagic trophic pathways in a subalpine lake. Canadian Journal of Fisheries and Aquatic Sciences 63:2608-2620.

Wong, M. C., C. H. Peterson, and M. F. Piehler. 2011. Evaluating estuarine habitats using secondary production as a proxy for food web support. Marine Ecology Progress Series 440:11-25. 